\title{
〔審査付論文 (研究論文)]
}

\section{経済成長を図るための非公共目的を包含する 土地収用法制度の弊害要因 \\ 一ASEAN諸国におけるマレーシアの事例からの考察—}

The Negative Effect Factors of the Land Acquisition System that Encompasses Non-Public Purpose for Economic Growth

- The Consideration from the Case of Malaysia in ASEAN Countries-

Yuichi OHYA : Graduate School of International Management, Yokohama City University

The Land Acquisition (Amendment) Act of 1991 in Malaysia for economic growth has institutionally enabled arbitrary land acquisition. This paper reveals what is the fundamental determinant of the negative effects on the legal system concerning land acquisition for economic growth. As a result of this study consideration, the article of property rights within the limits of the law enables governments to have a broad discretionary power and liberalizes policies governments can implement. However, this study concludes policies that make light of personal assets will obstruct economic growth in the long run.

Keywords : land acquisition, property rights, social public welfare, administrative discretion, corruption, Malaysia

\section{1.はじめに}

マレーシアにおける土地収用制度は, 公共目的 や経済発展に有益という目的で必要とされる土地 に対して, 土地の収用権限を持つ州当局が土地の 所有者に補償を行うことで, その所有する土地を 強制的に供させる制度である。

ASEAN諸国においても公共目的のための土地 収用（ベトナムにおいては土地回収，ラオスにお いてはLand Requisition）制度が定められており, ミャンマー, ラオスを除いて, 社会資本の整備や 国防等の安全保障のためという具体的な収用要件 が定められている。
特にベトナム, マレーシアは公共目的の土地収 用に加えて, 経済発展のための土地収用を認めて いることに特徵がある。経済発展を目的とする土 地収用の利点は, より生産性の高い事業者に土地 の所有権を移すことで, 土地利用の効率性を増大 させ, 経済成長の促進に寄与することである。べ トナムにおける経済成長を図る土地回収は, 工業 団地等を建設する場合に限られているが, マレー シアで土地収用が可能な地域は土地収用法 (Land Acquisition Act 1960) 上は限定されておらず, 法人が営利事業のための土地収用を行うことも認 められており, この点, ベトナムとの違いがあ る(1)。以下, 本稿では「公共目的の土地収用」と 
区別するため, マレーシアにおける経済発展を図 る営利事業のための土地収用のことを,「非公共 目的の土地収用」と便宜的に呼ぶこととする。

非公共目的の土地収用の制度的課題として，私 企業の利益に直結してしまうがために贈収賄の問 題が生じ得ることがある。多くの国において贈収 賄の存在が問題となっているが，本研究は，非公 共目的の土地収用の運用と贈収賄が結び付いた場 合，経済政策の遂行に対してどのような悪影響を 与えるか，また，それは法制度設計上どのような 要因に拠るのかを検討をする。

本稿の構成は以下の通りである。2 で既存研究 を整理し, 各国の土地収用と土地収用制度の弊害 要因の観点から考察の視点を整理する。3では, マレーシア独立後の経済政策の変遷と1991年土地 収用法改正へと至る経緯を踏まえた上で，マレー シアの所得格差の推移を分析する。また， 1960年 に制定された土地収用法の収用要件と1991年改正 法との収用要件の違いを示す。そして, マレーシ アにおける污職及び贈賄に関する調査結果と裁判 上で明らかとなった州政府関係者への贈賄に関し て示す。 4 で行政を拘束し, 立法への条件付けを することになる連邦憲法の規定からマレーシアに おける三権分立の特徴, 財産権及び土地行政にお ける連邦と州との権限配分に関してマレーシアの 法制度を整理する。 5 で，これまで確認した事項 を踏まえ, 非公共目的の土地収用における制度的 課題と経済政策への弊害要因に関して考察し, 結 論を述べる。

\section{2. 先行研究のレビュー}

\section{(1) 土地収用}

農地への土地収用の適用は急速に工業化してい る国々，特に中国とインドで顕著となっている2)。 Ghatak and Mookherjee(2014) ${ }^{2)}$ は, 工業化の過 程で農地を収用された農家への補償政策を分析し ている。Dell'Angelo et al.(2017) ${ }^{3)}$ は，27カ国に おける56の事例の内44のケースで共有地 (commons) が土地収用の対象となっていること を示しており，その半数以上は小規模農地であっ た。

アジア地域における土地収用を扱ったものとし て, 宮本 $(1993)^{4)}$ はマレーシア, タイ, インド
ネシア, フィリピンにおける公共用地の取得制度 に関して比較調査している。Ooi and Sirmans $(2004)^{5)}$ は，シンガポールの土地収用における資 産効果の存在を実証している。

ベトナムの土地回収に関して, 石田 $(2006)^{1)}$ は, 土地使用権の市場化がベトナムの土地制度に もたらしている制度変化と経済開発を目的とする 土地回収の紛争が提起している問題を明らかにし ている。Tuyen et al.(2014) ${ }^{6)}$ は家計の生計に及 ぼす農地損失の影響に関して定量的に立証してい る。農地損失が成人 1 人当たりの収入と支出に及 ぼす悪影響についての計量的根拠は見出されず， 農地損失は非農業ベースの生活の選択にプラスの 影響を及ぼし，家計の福祉に間接的にプラスの影 響を及ぼしていることが示されている。

ASEAN以外に目を向けると, 中国の土地収用 を調査したJu et al. $(2016)^{7)}$ は，都市化における 土地収用が農家の労働配分の決定に影響を与える かを実証している。その結果, 土地の減少は, 世 帯の非農業労働配分の確率とシェアに有意な正の 効果をもたらすことを明らかにしている。中国の 土地収用の弊害に関するのものとして, 平松 $(2012)^{8)}$ は，収用制度は統一的な法律が制定され ておらず，場当たり的に制定改廃される行政立法 が社会に混乱をもたらす要因となっているという 懸念を示している。江 $(2013)^{9)}$ は，土地収用に 伴う利益が, 中国では乱開発と贈収賄事件に繋 がっていることを報告している。佐藤 $(2012)^{10)}$ はインドの土地収用問題に関して, 経済学的及び 法学的な理論上の課題を整理している。

中南米における土地収用を扱った文献は，散見 され，逐一列挙しないが，ブラジルの土地収用を 扱ったものは, Miyasaka Porro and Shiraishi Neto $(2014)^{11)}$ がある。

アフリカにおける土地収用を扱った先行研究は 近年増加傾向にある。最近の研究は, German et al. $(2013)^{12)}$, Nolte and Voget-Kleschin $(2014)^{13)}$, Kleemann and Thiele (2015) ${ }^{14)}$ がある。

\section{（2）土地収用制度弊害要因}

日本国内では，行政法学の中で論じられる法制 度設計の大枠に関して, 効率性と正義性（公平性 及び平等性）の観点が挙げられている（平井 $1995^{15)}$ ，阿部1996 $\left.{ }^{16)}\right)$ 。経済学が想定する厚生の 
概念と, 法学の中で論じられる厚生の意味合いが どの程度一致するかに関しては検討が必要になる が, 社会的厚生を如何に確保するかという経済学 的視点からの議論は十分ではない。

污職に関する実証研究の数は多い。最近の研究 では, Cooray et al. (2017) ${ }^{17)}$ は, 污職の増加と 経済統計には現れない経済活動（shadow economy）の拡大が公的債務を増加させることを 示している。 $\operatorname{Beblavy}(2007)^{18)}$ は, 污職を防止す るための方策として, 污職の恩恵を減らし, 污職 のコストを高め, 污職を暴く確率を高め, 行政の 裁量を減少させる措置を提案している。

\section{（3） マレーシアにおける土地収用に関わる文献}

Xavier (2002) ${ }^{19)}$ は, 法学の観点からマレーシ アの土地収用における立法上の問題を指摘してい る。藤本 $(1997)^{20)}$ は, 数量的な根拠を示してい るわけではないが, 収用の要件を定める法第 3 条 の改正は, 開発の遅れていたマレー人土地保留地 への土地収用を利用した開発を図るため及び製造 業拡大のための改正であったと指摘している。 Salih and Yusof(1989) ${ }^{21)}$ は, 1971年から1990年 にかけて実施されたNew Economic Policy(新経 済政策，以下NEP）終了後の分配政策の課題と して，土地の経済構造に関して規制緩和と自由化 の余地が未だ大きいと指摘している。1995年の総 選挙時には, 土地収用に関して, マレー人農民が 政府への批判行動を起こした州において, 政府批 判キャンペーンを先導した野党勢力であるPAS (Partai Islam Semalaysia) が得票率を伸ばして いることが報告されている(2) (鳥居 1996) ${ }^{22)}$ 。法 改正による土地収用が国民の反発心を惹起する面 があったことは否定できない。

マレーシアにおける事業者と政治家との結び付 きが事業に影響を与えることを示す研究としては 張 $(2005)^{23)}$, ハサン-ザキーパクリアザド・篠原 $(2005)^{24)}$ がある。ハサンーザキーパクリアザド . 篠原 $(2005)^{24)}$ は, 政治家への贈賄を通じて行政 が誤りのある行動を取り得ることを示している。

\section{(4) まとめ}

行政裁量, 社会的厚生（社会的総便益）及び污 職（贈収賄及び賄賂）の3つの観点から法制度設 計に関して同時に考察している既存研究は十分で はない。また，土地収用を制度設計及び弊害の 2
つの観点から考察している既存研究も不十分であ る。

1991年のマレーシアにおける土地収用法の改正 は, 経済政策としての法改正であり，かかる法改 正を考察するに当たっては，法制面のみならず， 経済政策としての適否をも勘案する必要がある。 しかしながら、マレーシアの土地収用に関する研 究は, 収用に伴う正当な補償に関する研究蓄積は あるが(19)25)26)，土地収用を法制面及び経済政策の 両面から同時に考察を試みる研究は十分に行われ ていない。

従って, 本研究では, ASEAN諸国において先

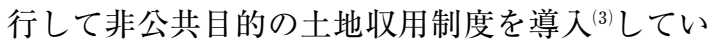
るマレーシアに着目し, 非公共目的の土地収用の 運用と贈収賄が結び付いた際の弊害及びこの制度 的要因を解明する。マレーシアにおける土地収用 の事例から, 非公共目的の土地収用における制度 的課題と経済政策への弊害要因に着目して議論を 進める。

\subsection{1年土地収用法改正へと至るマレー ア独立後の経済政策の変遷}

ここではマレーシアの概略を示し, その経済政 策の変遷と1991年土地収用法改正へと至る経緯を 踏まえた上で, マレーシアの所得格差の推移に関 して分析する。また，1960年土地収用法と1991年 改正法との収用要件を比較する。そして, マレー シアにおける污職及び贈賄に関する調查結果と裁 判上で明らかとなった州政府関係者への贈賄に関 して示す。

\section{（1） マレーシアの概略と経済政策の変遷}

マレーシアは，1957年 8 月31日にマラヤ連邦と してイギリスから独立している。1963年にボルネ オ島に存する現在のサバ州とサラワク州がマラヤ 連邦と統合し，マレーシアが成立している( ${ }^{(4)}$ 。マ レーシアは立憲君主制（ウェストミンスター型の 議院内閣制）を取り，13の州（マレー半島11州, 北ボルネオ島 2 州）から成る連邦制国家である。 2015年現在の人口 3,099 万人のうち, マレー人を 中心とするブミプトラ（Bumiputera「土地の子」 の意）が $61.8 \%$, 華人が $21.4 \%$ ，インド人が $6.4 \%$ を占める多種族国家である27)。イギリスからの独 立後は, 政府が市場に介入しないレッセフェール 
と称される自由放任主義経済体制を取っていた。 しかし，1969年にマレー人と華人との経済格差を 背景に発生した種族暴動（5月13日事件）をきっ かけに，種族間経済格差の是正及び貧困の削減を 重点的な政策目標とするNEPが1971年から1990 年にかけ導入されている(5)。しかし，NEP終了後 の経済政策は，所得再分配の前段階として，経済 成長が必要との認識から, 経済成長のためには一 時的な格差の拡大は止む無しとする政策が実施さ れた。この指向は，NEP終了後の1991年に改正 された土地収用法にも窥い知ることができる。実 際, 所得の不平等度を表すマレーシア全体でのジ 二係数は1989年に0.446で下げ止まりを示し， 1990年代に入ると，ジニ係数は上昇とその後 1997 年まで0.456から0.459の間で停滞を示している。 1999年は0.443と格差の縮小を示しているが，そ の後は再び数值が上昇している（図 1$)^{28)}$ 。NEP （1971-1990）終了後は，1991年から2000年にかけ てNational Development Policy（国民開発政策, 以下NDP）が実施されている。

種族ごとのジニ係数に着目すると（図 2 ), NDP期間中は, 1990年代後半まで各同種族間の 所得格差は拡大している。華人間の数值は1997年 にブミプトラ及びインド人に先行して減少を示し ているが，1997年から2002年にかけて再び華人間 の数值は格差の拡大を示している。インド人は,

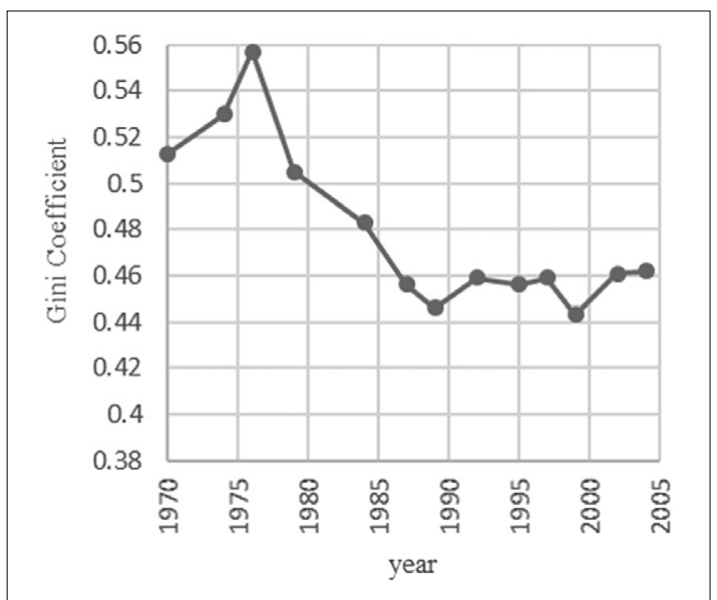

図 1 マレーシア ジニ係数の推移1970-2004 (出所) Economic Planning Unitより筆者作成

(注) $1970,1974,1976,1987$ 年はマレー半島のみのデータ

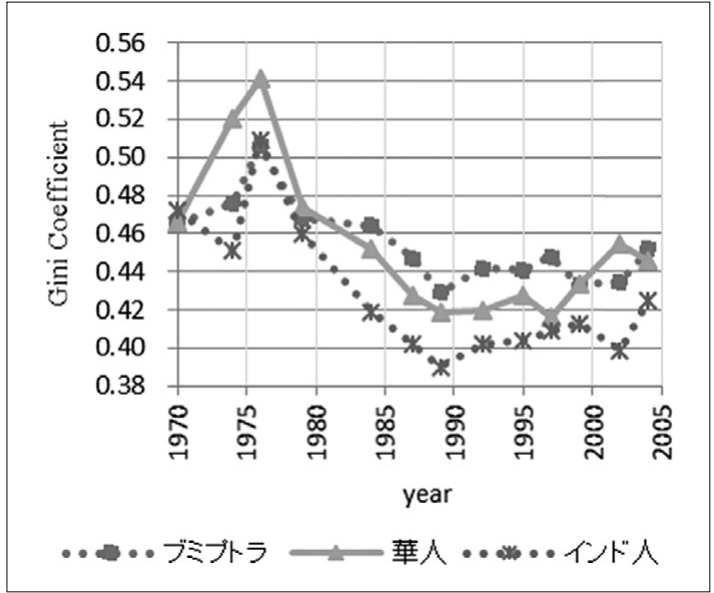

図 2 種族別ジニ係数の推移 1970-2004

(出所) Economic Planning Unitより筆者作成

（注） $1970,1974,1976,1987$ 年はマレー半島のみのデータ

ブミプトラ及び華人と比較すると, 同種族間の格 差は小さい状況でジニ係数は推移しているが, NDPにおけるインド人間の格差の縮小はブミプ トラ及び華人に劣後している。

種族間の所得格差に関して見ると（表 1)，ブ ミプトラと華人間の所得格差はNEP下で縮小し ていたが，NDP下では1997年までは格差の拡大 へと転じている。ブミプトラとインド人の所得格 差も同様にNEP下では縮小へと向かっていたが,

表 1 種族間及び地域間所得格差の推移 (中央値)

\begin{tabular}{|c|c|c|c|}
\hline year & $\begin{array}{c}\text { ブミプトラと華 } \\
\text { 人の所得比率 }\end{array}$ & $\begin{array}{c}\text { ブミプトラとイン } \\
\text { ド人の所得比率 }\end{array}$ & $\begin{array}{c}\text { 農村と都市 } \\
\text { の所得比率 }\end{array}$ \\
\hline 1970 & $1: 2.23$ & $1: 1.62$ & $1: 1.91$ \\
\hline 1976 & $1: 2.06$ & $1: 1.55$ & $1: 1.97$ \\
\hline 1979 & $1: 1.94$ & $1: 1.54$ & $1: 1.83$ \\
\hline 1984 & $1: 1.82$ & $1: 1.33$ & $1: 1.74$ \\
\hline 1987 & $1: 1.73$ & $1: 1.31$ & $1: 1.61$ \\
\hline 1989 & $1: 1.73$ & $1: 1.31$ & $1: 1.59$ \\
\hline 1992 & $1: 1.76$ & $1: 1.33$ & $1: 1.86$ \\
\hline 1995 & $1: 1.76$ & $1: 1.36$ & $1: 1.85$ \\
\hline 1997 & $1: 1.84$ & $1: 1.48$ & $1: 1.87$ \\
\hline 1999 & $1: 1.75$ & $1: 1.38$ & $1: 1.80$ \\
\hline 2002 & $1: 1.74$ & $1: 1.34$ & $1: 2.00$ \\
\hline 2004 & $1: 1.66$ & $1: 1.33$ & $1: 2.69$ \\
\hline
\end{tabular}

(出所) Economic Planning Unitより筆者作成

（注）1970，1976年はマレー半島のみのデー夕 
NDP下では1997年までは格差の拡大を示してい る。インド人と華人との所得格差はNDP下にお いて，1997年までは格差の縮小傾向にあったが, それ以降は2002年まで格差が拡大している。

農村と都市の所得格差に関して（表 1), NEP 下では格差の縮小傾向にあったが, NDP初期に 格差の拡大を示し, その後は1995年と1997年の両 年に格差が縮小している。

これらのデータの推移を踏まえると，主に1990 年代後半からNDP終了時にかけて, 所得の再分 配が機能したとみられる。入手したデー夕は各年 データではないが，1990年代のNDP期間中マレー シア全体でのジニ係数は, 1995年及び1999年に数 值の減少を示している。また, 農村と都市の所得 比率に関しても1995年及び1999年は, 格差の縮小 を示している ${ }^{(6)}$

\section{（2）1991年土地収用法改正}

1991年における土地収用法の改正は, NDPの 初年度にあたる。1960年に制定された土地収用法 は，土地収用を行うことができるケースは，公共 目的の場合に制限されていた29)。1960年の土地収 用法 3 条は収用の要件として,「公共目的もしく は個人又は法人が州当局の判断に基づき公益事業 を行う場合, 又は鉱業, 住居, 農業, 商業, 工業 目的による場合には, 州当局は土地を収用するこ とができる」と規定されていた。

\section{(1) 収用要件の拡大}

しかし，1991年の改正土地収用法は収用の要件 を拡大し, 州当局がマレーシアの経済発展又は一 部の地域や社会のいかなる階層（any class of the public）のためにも経済的に有益であると判 断するあらゆる事業のために，いかなる個人又は 法人に土地を供するための土地収用を州当局が行 うことが可能となった（改正土地収用法 3 条）。 この収用の要件を定める法 3 条の改正の背景には, 既に示した通り，NEP終了後の経済政策の方針 として, 所得倍増と分配計画があり, 所得再分配 の前に経済成長率の向上が必要との認識がある。 この政策目標を遂行するための法 3 条の改正であ ると考えられる。

ASEAN諸国において，マレーシアのみならず, ベトナムにおいても経済発展のための土地回収が 認められている。ベトナムにおいては, 国益及び
公益のための社会経済発展を図る土地回収は，工 業団地, 輸出加工区，八イテク区，経済区及び新 都市地区を建設するプロジェクト, 政府開発援助 （ODA）に基づく投資プロジェクト並びに国会が 国家の重要プロジェクトとして，投資方針を決定 した場合に限られている (土地法62条)。しかし ながら，マレーシアにおいては土地収用が可能な 地域は限定されておらず，都市計画に関して無計 画な土地収用も制度上実行されかねない。

\section{(2) 污職及び贈賄の発覚}

マレーシアにおいて, 土地収用を行うには州当 局の許認可を要する。しかしながら, マレーシア 証券取引所の上場企業を対象とした調査である $\lceil K P M G$ Malaysia Fraud, Bribery and Corruption Survey 2013」(7) 30) は, マレーシアで 事業を行う際の企業の贈賄と污職に対する認識を 示している。土地収用をめぐる裁判においては, 州政府関係者への贈賄と事業の許認可との関係が 裁判の過程から明らかになっている(8) 31)。事業の 許認可に関わる贈賄は, 申請手続きのための着手 金という意味合いもあると思うが，これらの調査， 裁判の事例及び先行研究を踏まえると, 全ての土 地収用において適当な審查後に効果的な収用が行 われているのかに関しては懐疑的とならざるをえ ない(9)。

\section{4. マレーシアの法制度及び土地行政の構造}

ここでは，考察の前提条件となるマレーシアの 法制度と土地行政の構造について整理する。

\section{(1) マレーシアの法制度}

マレーシアはイギリス法の影響を受け三権が分 立する体制をとっているが，相対的に行政の力が 強くなっていることにその特徵がある。連邦憲法 から付与されると規定されていた裁判所の司法権 は, 1988年の連邦憲法の改正により, 連邦法に よって付与される司法権であると改められた。こ れにより，司法権の独立が抹消されている ${ }^{(10)}$ 。

\section{(1) 連邦憲法の最高法規性}

連邦憲法の 4 条 1 項で, 連邦憲法が連邦の最高 法規であることが示されている。また, 同条同項 において, 独立日 ${ }^{(11)}$ 以後に制定され, かつ連邦憲 法と適合しない一切の法律が, 連邦憲法と適合し ない範囲において無効となることが示されている。 
また, 同 4 条， 128 条により, 連邦の各裁判所に 違憲審査権が与えられている。

\section{(2) 連邦憲法における財産権の規定}

行政がどのような経済政策を実行することがで きるのかに関しては, 行政を拘束する憲法及び法 律の条文の規定如何に依ることになる。連邦憲法 が連邦の最高法規であり, 裁判所に違憲審査権が 与えられ，連邦憲法と適合しない法律が適合しな い範囲において無効となることが規定されている 以上，憲法の規定に違反する立法は違憲となる。 しかしながら，財産権の制限を伴う経済政策を実 行するに当たって，財産権について規定している マレーシアの連邦憲法の13条 1 項は「いかなる者 も法律に依ることなしにその財産を奪われない」 としている。財産権に関しては法律の留保に付さ れ, 制定法の内容如何で財産権に制限を加えるこ とが可能となっている。このため, 財産権の制限 に関して行政に柔軟な裁量を付与する立法を行う ことができる規定となっている。マレーシアの連 邦憲法は, 法律の枠内でのみ財産権を保障してい るのである。

また，同条 2 項では「いかなる法律も正当な補 償（adequate compensation）なしには財産を強 制的に収用及び使用することを規定し得ない」と 定められている ${ }^{(12)}$ 。財産権の制限に関しては, 制 定法によること及び正当な補償の 2 つの要件を充 足することを要する。

\section{(3) 司法審査の制限}

法律の留保に付され，行政が柔軟な政策を行う ことを可能にする財産権の規定に加え，更に，マ レーシアでは行政に対して異議を申し立てること を困難にする司法審査を制限する規定が存在する。 違憲審査権に加え, 裁判所法第 1 附則及び高等法 院規則第53条に基づき, 上位裁判所 (Superior Court $)^{(13)}$ に行政府の行為に対する司法審査権が与 えられている ${ }^{34)}$ 。しい,「最終条項 (Final Clause)」と呼ばれる特別条項によって, 違憲審 查と司法審査はしばしば適用を除外され, その適 用が制限されている。この最終条項は連邦憲法そ のものにも規定がなされた条項があり, 法律（少 なくとも所得税法）の中にも規定がなされてい る(41)。マレーシアの土地収用法では, 8 条 3 項に この最終条項の規定がある。
違憲審査及び司法審査の基本原理は権限踰越 (Ultra vires）の法理である。州政府が実行する 土地収用に関してその無効を主張するには, 土地 を収用される土地所有者が当該土地収用に対して 恣意（mala fide or bad faith）があることを証明 しなければならない。すなわち, 当該収用の目的 が土地収用の要件を定める法 3 条の要件の範囲内 にないこと又は土地収用に関して州政府に権限の 濫用があることを訴訟において，立証しなければ ならない36)。この立証は単なる恣意の疑いがある ということだけでは不十分であると裁判で判示さ れている ${ }^{37)}$ 。恣意のある土地収用に対してその無 効を主張するには，収用を受ける土地の所有者が， 恣意が存在するという明確な証拠を挙げなければ ならない。

\section{（2）マレーシアの土地に関する立法及び行政管轄}

ここでは, 連邦と連邦を構成する州との土地に 関する立法権限及び行政管轄について示す。

マレー半島においては, 国家土地法典 (National Land Code 1965）が土地に関する一般法となっ ている。ボルネオ島に位置するサラワク州及びサ バ州においては, サラワク州土地法典 (Sarawak Land Code 1958）及びサバ州土地条例（Sabah Land Ordinance 1930）がそれぞれの州に適用さ れている。

マレーシアでは土地に関する権限は連邦を構成 する州に置かれており（連邦憲法80条及び連邦憲 法第 9 附則List II ), 州が保有する土地が私人に 譲渡（alienation）されることにより，私的所有 権が発生する。そして, 州から譲渡された土地を 私人の間で売買することで土地の流通が行われる 制度となっている。

マレーシアでは, 連邦憲法80条及び連邦憲法第 9 附則において, 連邦政府と州政府との行政権の 配分が定められている。立法権限管轄を定める連 邦憲法第 9 附則List II に土地の強制収用を含む土 地の関連事項に関して州に立法権限があることが 示されている。このため, 州の立法権限管轄を定 めるList II に規定された事項に関して, 州は独自 の地域的効力を有する州法を制定することができ る (連邦憲法73条)。州に立法権限の存する事項 は州の行政管轄となる（連邦憲法80条 1 項）。

連邦の法律と州の法律が矛盾する場合は, 州の 
法律は連邦の法律と適合しない範囲において無効 となり，連邦の法律が優先される（連邦憲法75 条)。このことにより政策の国内統一性が担保さ れている。更に, 連邦議会は, 複数の州の法律に 統一性を持たせることを目的に，州に立法権限の ある事項に関しても立法権を有する（連邦憲法76 条)。連邦法は州法の上位法となり, その効力は マレーシアの全土に及ぶ（連邦憲法73条）。しか し，連邦の行政権は連邦憲法第 9 附則List II が示 す州の管轄事項には及ばない（連邦憲法 80 条 2 項)。

一つの州あるいは複数の州にまたがる開発計画 に関しては，国王が関係機関との協議後(15)，当該 開発計画が国家の利益に資すると了承し, 開発計 画公表後, 国王が該当地域を開発地域として宣言 すると, 当該開発計画に関係するいかなる事項に おいて, 州のみが立法権を有するとされる事項で あっても, 連邦議会が当該開発計画及びその一部 を発効させる権限を持つ（連邦憲法92条）。

マレーシアの土地行政は上記の立法・行政管轄 を前提とし，開発地域として指定された場合を除 いて，州政府が裁量を持つ体制となっている ${ }^{(16)}$ 土地収用に関する許認可権限も州政府が有し（連 邦憲法第 9 附則List II 及び80条)，この行政管轄 に反する連邦法を制定することはできない。

\section{5. 考察と結論}

マレーシアにおける法律の留保に付された連邦 憲法13条の規定は, 法律の留保に付されていない 場合と比較して, 人権制約の範囲が広くなり, 理 論上新たな立法問題を引き起こす可能性がある。 度重なる連邦憲法の改正はこれまで立憲主義を劦 かしてきたが(10)，安易な財産権の制限を防止する ため, 連邦憲法13条を改正し, 行政の裁量の縮小 が図られても良いのではないか。

法律の留保に付した憲法の規定は, 行政が実行 することができる政策の自由度を高める。だが, 個人の財産を軽んじるような政策は資産に対する 制度的信用を欠落させ，国民の意欲を削ぐため， 最終的には経済成長を阻害することが考えられる。 このことは，マレーシアのみならず，他の国にも 該当するものである ${ }^{(17)}$ 。非公共目的の土地収用に 関して, 事業者は, 土地収用を利用して用地を取
得することで, 土地の売買交渉の過程で生ずる土 地の売値の上昇を回避し, 土地取得の費用を小さ くしょうとする誘因がある。このことは事業者の 土地収用着手要因となる。

行政の広範な裁量は柔軟な行政の判断を可能に する。しかしその一方, 行政の裁量の範囲が大き いと, 社会的厚生最大化のための行政の最適な判 断からは乘離した事業の許認可へと行政が誘導さ れる範囲も大きくなる。これは, 行政の権限を利 用して自己の利益の増大を図ろうとする経済主体 による行政への贈賄を通して発生する。行政への 私的利益の確保拡大を図るための贈賄は, 社会的 厚生を最大化するという行政が本来担うべき役割 を阻害する。この贈賄により，十分な審査が実施 されず，行政が誤りのある許認可を行い得る。 1997年における土地収用法改正時 ${ }^{181}$ に土地収用申 請に対する審査に際して, 公の利益及び事業の実 行可能性を考慮して審査すべき旨の規定が設けら れたが ( $3 \mathrm{~A}$ 条), この規定の趣旨は行政への贈 賄により没却されかねない。

以上の議論を踏まえて, 行政の土地収用（事 業）の許認可に関する法制度設計上の弊害要因の 普遍的な点を抽出すると, 以下の 3 点に整理でき る。

1. 法律の留保に付した憲法の規定が立法の自由 度を高め, 行政に広い裁量（柔軟な裁量）を 持たせる。

2. 行政が広い裁量を持つがために, 政策目標の 遂行に負の効果を与える判断及び国民の信用 を損ねる判断を行政が行い得る。

3. 政策目標の遂行に負の効果を与える行政の判 断は, 広範な裁量を有する行政の権限を利用 しようとする贈賄を通して誘発される。

各国の憲法規定の内容にも依拠するが，憲法に 基づき立法がなされ, 憲法と法律により行政が運 営されている国家においては, 上記のことはマ レーシアに限らず，他の国々においても共通の特 徵となり得る。行政も失敗をすること及び社会的 厚生の拡大を顧みない判断を行うことを予め念頭 に置いた上で，失敗の程度を小さくすることを見 越した制度設計を行うことも法制度設計上の重要 
な観点であると思われる。

司法審査も含め，法規による行政裁量の更なる 統制は先進国入りに向けたマレーシアの今後の課 題であるといえる。住民による直接選挙によって 構成される州議会が制定する州法により自浄的に 州政府の裁量を狭めることも制度上は可能である。

さて, 本研究では, $\operatorname{NEP}(1971-1990)$ から NDP（1991-2000）にかけての政策の変遷を踏ま えて考察してきたが，NDP終了後，2001年から 2010年にかけてNational Vision Policy（国民ビ ジョン政策，以下NVP）が実施され，2010年か ら2020年にかけてはNew Economic Model(新経 済モデル，以下NEM）が策定されている。NDP （1991-2000）の理念として掲げられた「経済面で 公正・平等な社会」の実現が所得格差の面でより 実現へと向かってきているのは，図 3 が示すよう に2007年から2014年にかけてのことである ${ }^{(19)}$ 。非 公共目的の土地収用，すなわち，営利事業のため の土地収用制度の導入にあたっては, 当事者間で 売買の交渉ができる事項にも関わらず，なぜ私的 利益の拡大に直接寄与する土地収用制度を設ける のか, その制度導入の背景には, 格差是正のため の所得分配 ${ }^{20}$ における原資の確保や，迅速に経済 成長を促進することで貧困の削減を図る等の, 財 産権への侵害を是認させるような公共目的と関わ

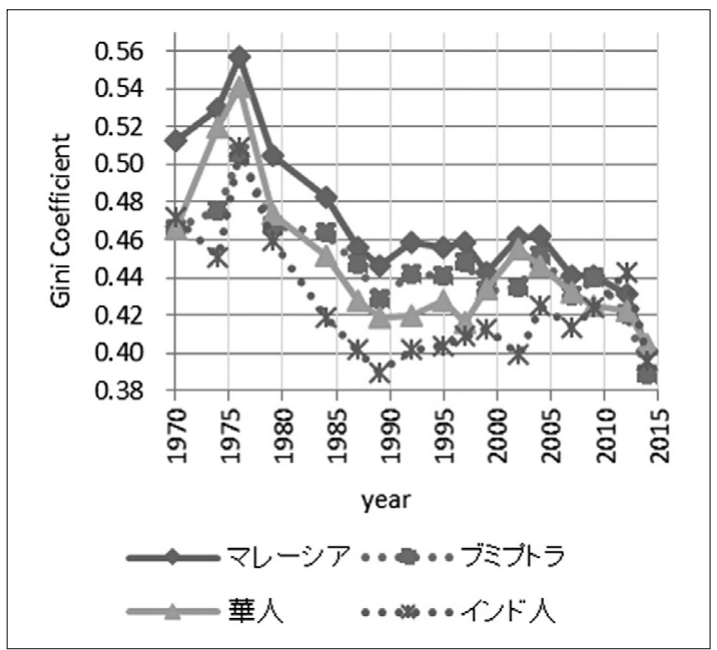

図 3 マレーシア全体及び種族別ジニ係数1970-2014 (出所) Economic Planning Unitより筆者作成

（注） $1970,1974,1976,1987$ 年はマレー半島のみのデー夕
る大義の存在は必須であろう。

非公共目的のための土地収用も可とする土地収 用法の改正はNEPからNDPへと移行した, NDP 初年度の1991年に行われているが，NDPから NVP及びNEMへと政策が移行する過程で土地収 用の実施がどのように変遷したか, さらにNVP 及びNEM下において具体的にどのような政策が 取られたか, またその政策が各種族へいかなる影 響を与えたかについては今後の研究課題としたい。

\section{謝辞}

本研究は匿名の査読者の方から貴重なご意見を頂戴した。 ここに謝意を表します。

\section{補注}

（1）また，マレーシアでは土地収用の補償額は，任意買収 の場合を除いて, 行政が決定する点においてもべトナ ムと差異がある。石田 $(2006)^{1)}$ は, ベトナムにおけ る2003年改正土地法下において, 土地回収に伴う補償 に関しては, 土地の所有者と事業者の当事者間で補償 額の合意が成立している場合には, その額が土地回収 に伴う補償額として採用されていることを報告してい る。

(2) PASは「UMNOの州」と呼ばれるジョホール州も含 めて全体として得票率を伸ばしたが, 獲得議席数は 1990年の総選挙の時と変わらず 7 であった。UMNO (United Malays National Organization) は与党連合 の最大政党である22)。

（3）ベトナムにおける経済開発目的の土地回収は，2003年 改正土地法では, 公共目的の土地回収とは明確に区別 されている。

(4) 1965 年にシンガポールがマレーシアから分離独立。

(5) NEPは, ブミプトラ政策とも称されるマレー人優遇 をその特徴としている。

（6）なお，1990年代におけるマレーシアの総選挙は1990年, 1995年及び1999年に行われていることに留意する必要 がある。

(7) 当該調査は有効回答数が明記されていないという問題 があるものの, 全上場企業のおよそ $10 \%$ に相等する企 業から回答を得ていることは明らかにしている。回答 企業の71\%が「ビジネスの遂行において, 贈賄 (bribery) と污職 (corruption) は不可避」と認識し, 更に $64 \%$ が「賄賂 (bribe) なくして, マレーシアで ビジネスを遂行することはできない」という認識を示 している。

（8） 4 年もの間承認がなされなかった土地開発の申請が, 
当該土地を所有する会社の株式30\%を州政府関係者に 与えるとすぐに州から開発の承認がなされた。当該裁 判では, 開発に必要な行政の許認可の承認を確保する 立場にあるという者たちが被控訴人の一人として, 裁 判の当事者となっている。

（9） 2004年の総選挙では与党の選挙公約として，2013年の 総選挙では与野党の選挙公約の一つとして污職の撲滅 が掲げられている。

(10) マレーシアの連邦憲法は2009年最終改正の時点で57回 の改正が行われている ${ }^{32)}$ 。この憲法の改正頻度は与党 連合BN(Barison Nasional) が連邦憲法の改正要件と なる議会の議席数 3 分の 2 を継続して確保してきたこ とが要因としてある。

(11) Merdeka Day：1957年 8 月31日

(12) 連邦憲法13条 2 項が要請する土地収用の際の正当な補 償金の算定基準は市場価格である（土地収用法第 1 附 則)。詳しくは, Grace Xavier(2002) ${ }^{19)}$ 又はその邦訳 版であるグレース・ザビエル (2006) ${ }^{33)}$ を参照せよ。 ただし，邦訳版はstateを州ではなく，国と訳出して おり, 土地行政における権限の記述に関して紛らわし い面がある。

(13) 上位裁判所は連邦憲法に基づき設置され，その判決は 先例拘束性を有する。上位裁判所は, 高等法院 (High Court of Peninsular Malaysia, High Court of Sabah and Sarawak), 控訴院 (Court of Appeal), 連邦裁 判所 (Federal Court) から成り, 連邦裁判所が終審 の裁判所である34)

(14) 最終条項の典型的な例は, 以下のようなものである。 「最終的かつ終局的である (final and conclusive)」, 「異議申立てや上訴, 司法審査, 無効判決, またはい かなる裁判所での審査にもなじまないものとする (shall not be challenged appealed against, reviewed, quashed or called in question in any court of law) 」35)。

(15) 国王は, 専門委員会の勧告を受け, 国家財政評議会 (National Finance Council), 国家土地評議会 (National Land Council) 及び関係する州政府と協議 を行う。

(16) 連邦は州政府に対して助言をすることはできる（連邦 憲法94条)。

(17) 土地所有権だけでなく, 土地の私的所有が認められて いない国における土地使用権に対してもそのような効 果の存在が考えられる。

(18) 1997年改正法では土地の収用要件の範囲が拡大され, 新たにレクリエーション目的による土地収用を行うこ とが可能となった。

(19) 2014年のジニ係数は, マレーシア全体では0.401, ブ ミプトラ 0.389 , 華人 0.405 , インド人 0.396 である。
（20）ただし，経済が発展途上の議会制を取る国においては， 経済成長の成果を最大限獲得議席数に反映させるため, 選挙の際の票の獲得に効果的な時期, 場所及び対象者 を図って分配を行う蓋然性がある。

\section{参考文献}

1 ）石田暁恵 (2006), 「土地回収制度を中心とするべトナ ムの土地制度変化に関する一考察」, アジア経済, 47 巻 8 号, pp.2-26

2) Ghatak, M., \& Mookherjee, D. (2014), "Land acquisition for industrialization and compensation of displaced farmers" Journal of Development Economics, 110, pp. 303-312

3 ) Dell'Angelo, J., D’Odorico, P., Rulli, M. C., \& Marchand, P. (2017), “The Tragedy of the Grabbed Commons: Coercion and Dispossession in the Global Land Rush” World Development, 92, pp.1-12

4 ) 宮本和明 (1993), 「東南アジア諸国における公共用地 取得制度の比較」, 都市計画論文集, 28号, pp. 445450

5 ) Ooi, J. T., \& Sirmans, C. F. (2004), “The wealth effects of land acquisition" The Journal of Real Estate Finance and Economics, 29(3), pp. 277-294

6 ) Tuyen, T. Q., Lim, S., Cameron, M. P., \& Huong, V. V. (2014), "Farmland loss and livelihood outcomes: A microeconometric analysis of household surveys in Vietnam” Journal of the Asia Pacific Economy, 19 (3), pp. 423-444

7 ) Ju, Q., Ni, J., Ni, D., \& Wu, Y. (2016), “Land Acquisition, Labor Allocation, and Income Growth of Farm Households" Emerging Markets Finance and Trade, 52(8), pp. 1744-1761

8 ) 平松弘光 (2012),「日本法からみた中国の土地収用制 度」, 総合政策論叢, 24号, pp.85-102

9 ) 江利紅 (2013),「中国における土地収用制度とその改 善に向けた課題 (1)」, 比較法雑誌, 46 巻 4 号, pp. 157-188

10）佐藤創（2012),「インドにおける経済発展と土地収用 --「開発と土地」問題の再検討に向けて」, アジア経済, 53 巻 4 号, pp. 113-137

11) Miyasaka Porro, N., \& Shiraishi Neto, J. (2014), "Coercive Harmony in Land Acquisition : The Gendered Impact of Corporate "Responsibility" in the Brazilian Amazon” Feminist Economics, 20(1), pp. $227-248$

12) German, L., Schoneveld, G., \& Mwangi, E. (2013), "Contemporary processes of large-scale land 
acquisition in Sub-Saharan Africa: legal deficiency or elite capture of the rule of law?" World Development, 48 , pp. 1-18

13) Nolte, K., \& Voget-Kleschin, L. (2014), “Consultation in large-scale land acquisitions: An evaluation of three cases in Mali” World Development, 64, pp.654668

14) Kleemann, L., \& Thiele, R. (2015), "Rural welfare implications of large-scale land acquisitions in Africa: A theoretical framework" Economic Modelling, 51, pp.269-279

15）平井宜雄（1995), 『法政策学〔第 2 版〕』, pp. 69-117, 有斐閣

16）阿部泰隆（1996）、『政策法学の基本指針』, pp. 79-93, 弘文堂

17) Cooray, A., Dzhumashev, R., \& Schneider, F. (2017), "How Does Corruption Affect Public Debt? An Empirical Analysis” World Development, 90, pp. 115127

18) Beblavy, M. (2007), "Costs of corruption and potential remedies from an economic point of view. "Ekonomický časopis (Journal of Economics), 7(55), pp.697-711

19) Xavier, G. (2002), "Land Acquisition in Malaysia”, in Tsuyoshi Kotaka and David L. Callies (eds), Taking Land: Compulsory Purchase and Regulation in Asian-Paciffic Countries, pp. 195-226, University of Hawaii Press

20）藤本彰三（1997）,「マレーシアにおける経済発展と土 地問題の変質」, 水野広祐・重富真一編, 『東南アジア の経済開発と土地制度』, pp. 225-262, アジア経済研 究所

21) Salih, K. and Yusof, Z. A. (1989), “Overview of the New Economic Policy and Framework for Post-1990 Economic Policy”, Malaysian Management Review, 24(2), pp.13-61

22）鳥居高（1996）,「1995年のマレーシア 最終段階へ向 かうマハティール体制」,『アジア動向年報1996』, pp. 350-356, アジア経済研究所

23）張開玫 (2005),「マレーシアにおける華人企業グルー
プの発展状況」, 東アジア研究, 42号, pp. 17-29

24）ハサンーザキ-パクリアザド・篠原武夫 (2005), 「半島 マレーシア・パハン州におけるスルタンの合法的権利 として慣習土地保有制度に関する研究」, 林業経済研 究, 51 巻 2 号, pp. 13-20

25) Alias, A., \& Nasir Daud, M. D. (2006), "Payment of adequate compensation for land acquisition in Malaysia” Pacific Rim Property Research Journal, 12 (3), pp. 326-349

26) Alias, A., Kamaruzzaman, S. N., \& Daud, M. N. (2010), "Traditional lands acquisition and compensation: The perceptions of the affected Aborigin in Malaysia” International Journal of Physical Sciences, 5(11), pp.1696-1705

27) Department of Statistics, Malaysia, https://www. statistics.gov.my/, 2016/1/20アクセス

28) Economic Planning Unit, Malaysia, http://www.epu. gov.my/en/household-income-poverty, 2016/9/19ア クセス

29) Financial Times, 2 August 1991, p.4.

30) "KPMG Malaysia Fraud, Bribery and Corruption Survey 2013”, https://www.kpmg.com/MY/en/ Issues AndInsights / ArticlesPublications / Documents/2013/fraud-survey-report.pdf, 2016/3/29アクセス

31) Stamford Holdings Sdn Bhd v. Kerajaan Negeri Johor \& Ors [1998], 1 MLJ 607

32) Constitution of Malaysia,"List of amendments"

33）グレース・ザビエル（2006）(訳 : 伊川正樹),「マレー シア」, 小高剛・デービットL. キャリーズ編, 『アジ ア太平洋諸国の収用と補償』, pp. 197-226, 成文堂

34）桑原尚子 (2009), 「マレーシア」, 鮎京正訓編, 『アジ ア法ガイドブック』, pp. 240-266, 名古屋大学出版会

35) 大村泰樹 (1997), 「マレーシアの憲法制度」, 作本直 行編, 『アジア諸国の憲法制度』, pp. 49-84, アジア経 済研究所

36) S. Kulasingam \& Anor v. Commissioner of Lans, Federal Territory \& Ors [1982], 1 MLJ 204

37) Yeap Seok Pen v. Government of the State of Kelantan [1986], 1 MLJ 449 